\title{
APROXIMACIÓN A UN NUEVO RÉGIMEN JURÍDICO DE LA CASA DEL REY
}

LUIS VACAS GARCÍA-ALÓS

Doctor en Derecho. Magistrado 


\section{APROXIMACIÓN A UN NUEVO RÉGIMEN JURÍDICO DE LA CASA DEL REY *}

POR

\section{LUIS VACAS GARCÍA-ALÓS}

Doctor en Derecho. Magistrado

Con la entrada en vigor de nuestra Constitución han surgido nuevas organizaciones e instituciones que, sin tener el carácter de Administración Pública —en el sentido tradicional de la expresión-, vienen realizando auténticas funciones de naturaleza jurídico-administrativa?. Como consecuencia de ello, materias tales como la extensión y los límites del acto administrativo $y$, sobre todo, el ámbito objetivo de la jurisdicción contencioso-administrativa se han visto directamente afecta-

(*) El presente trabajo está basado en la Tesis Doctoral, de próxima publicación, del autor de estas líneas.

1 Es el caso de las funciones que en materia de personal, régimen interior y gestión patrimonial vienen desempeñando las Mesas del Congreso y del Senado, dando lugar a la denominada "Administración Parlamentarian; las realizadas por el Pleno del Tribunal Constitucional; las desempeñadas por el Pleno del Consejo General del Poder Judicial, así como por las Salas de Gobierno de los Tribunales de Justicia, configurándose de este modo la llamada "Administración de la Jurisdicción»; y las realizadas por el Pleno del Tribunal de Cuentas, el Defensor del Pueblo, los Órganos de Gobierno de las Universidades, etc. Cfr., a este respecto, VACAS GARcíA-Alós, L.: "Aplicación de la Ley de Procedimiento Administrativo en el ámbito interno de los órganos jurisdiccionales», en Actualidad Administrativa, n. ${ }^{\circ} 22,1987$. 
das por el valor normativo del Texto fundamental. Y asi, y a modo de ejemplo, el contencioso-administrativo ha dejado de configurarse como mero proceso al acto, para pasar a convertirse en destacado instrumento garantizador de los derechos fundamentales de la persona.

De esta forma, la influencia del Derecho Constitucional en la reconstrucción de los límites formales del Derecho Administrativo ha sido más que notoria ${ }^{2}$. Con arreglo a este planteamiento, derechos tan fundamentales $y$ tan emblemáticos como el derecho a la tutela judicial efectiva han dejado de ser simples declaraciones programáticas y teóricas, conteniendo en la actualidad un componente práctico, de directa vinculación y de aplicación inmediata por parte de todos los poderes públicos. Se hace así efectiva realidad la concepción de la Constitución como "sistema de valores, cuya observancia requiere -en palabras del profesor Cascajo ${ }^{3}$ - una interpretación finalista de la norma fundamental's.

Pues bien, entre las apuntadas "nuevas Administraciones Públicas" destaca una que, a pesar de su significativa importancia -está adscrita al ámbito organizativo de la Jefatura del Estado-, no ha sido objeto hasta ahora de destacada atención por parte de la doctrina. Nos estamos refiriendo a la que se ha venido en llamar "Administración Real», incardinada en la Casa del Rey. Se trata, de una Administración Medial integrada en una organización administrativa estatal, con funciones de apoyo y asesoramiento a la Corona $y$, al mismo tiempo, con cometidos ejecutivos de dirección, inspección y coordinación de los servicios personales y materiales que necesita la Jefatura del Estado para el cumplimiento de las altas funciones que tiene encomendadas.

2 El surgimiento de estas nuevas Administraciones Públicas no sólo supone la clara influencia del Derecho Constitucional en la reconstrucción de los límites formales del Derecho Administrativo, sino que implica, además, y a juicio del profesor Garrido Falla, "el derribo de la teoría de la personalidad única de la Administración Pública y subsiguiente definición del Derecho administrativo como el Derecho propio y específico de las Administraciones públicas en cuanto personas. Se trata también -en opinión del referido profesor- de la necesidad de revisar toda la concepción orgánico-subjetiva de la Administración Pública y, por ende, la definición del Derecho Administrativo, del acto administrativo y de los límites formales de la competencia de la Jurisdicción contencioso-administrativan. Cfr., en este sentido, GarRido Falla, F.: Reflexiones sobre una reconstrucción de los límites formales del Derecho Administrativo español, Madrid, 1982, pág. 61.

3 CASCAjo CASTRO, J. L.: "Los valores y la Constitución", en Estudios de Derecho Constitucional. Homenaje al prof. Rodrigo Fernández Carvajal, Murcia, 1997, pág. 127. 
Y esa escasa atención doctrinal que hasta la fecha ha despertado la Casa del Rey, como institución administrativa, unida a la, a nuestro juicio, equivocada traslación del principio de inviolabilidad regia a la gestión desempeñada por el Jefe de la Casa del Rey en el ejercicio de sus funciones jurídico-administrativas y jurídico-presupuestarias, nos ha llevado a profundizar en el estudio, desde el punto de vista del Derecho Constitucional, del control jurisdiccional de la Administración de la mencionada Casa del Rey.

Dejando al margen los antecedentes normativos remotos de la Casa del Rey, entre los que resultan de forzosa mención el Reglamento de 1 de enero de 1707, sobre el personal al servicio del Rey en su esfera doméstica y el Reglamento de 18 de marzo de 1749, sobre la Casa del Rey ${ }^{4}$, la Constitución de 1812 dedica los artículos 213 a 221 a regular con particular precisión - superior a la de otros textos constitucionales - la dotación de la Familia Real. Y así el Rey nombraba a un Administrador, que era quien recibía directamente de la Tesorería $\mathrm{Na}$ cional las asignaciones en concepto de dotación de la Casa del Rey y de alimentos de la Familia Real. Uno de los orígenes más remotos del administrador del Real Patrimonio se encuentra en las instituciones del Bayle General y del Intendente, creado en la rúbrica 3. ${ }^{\text {a del Cuerpo de }}$ los fueros de Valencia del año 1240, y que según los Reales privilegios de 15 de julio de 1340 y de 1 de abril de 1384 tenía jurisdicción privativa en todo lo concerniente a la administración y gobierno de dicho Real Patrimonio 5 .

Es de destacar que el citado Administrador era quien en realidad gestionaba la dotación real y, lo que es más importante, a los efectos del contenido del presente estudio, quien respondía de dicha gestión $y$ de las acciones que pudieran entablarse como consecuencia de la misma.

4 Otros antecedentes son las Ordenanzas de 29 de mayo de 1840 y 23 de enero de 1848, por las que se reconocen la autonomía del títular de la Corona en la organización y funcionamiento de su Casa.

5 Sobre estas instituciones, cfr. Branchat, V.: Tratado de los derechos y regalias que corresponden al Real Patrimonio en el Reyno de Valencia y de la jurisdicción del Intendente como subrogado en lugar del antiguo Bayle General, imprenta de Joseph y tomás de Orga, Valencia, 1784. 
Con posterioridad al texto de Cádiz no ha sido tónica dominante de las normas constitucionales la detallada regulación de estas funciones de administración de la dotación regia, por considerarse que era cuestión propia de la legalidad ordinaria ${ }^{6}$. Tan sólo se hacía referencia al comienzo de cada reinado como momento en el que se establecía la dotación de la Corona.

La singularidad de nuestro estudio se debe, pues, a la dificultad de constituir un control jurisdiccional en el ámbito temporal de la vigencia de tales Constituciones del siglo XIX, lo cual, por lo demás, supondría introducir un elemento extraño y absolutamente incompatible con la mentalidad de los inspiradores o autores de los indicados textos constitucionales y con la idiosincrasia general de la respectiva época. $Y$ esto sin olvidar que el control sobre los ingresos y gastos de la Corona fue una característica destacada de las manifestaciones parlamentarias de la Edad Media, pues desde el siglo XIII fue evolucionando la función parlamentaria de control de los fondos públicos. Sirvan de ejemplo, en este sentido, los debates de las Cortes convocadas por Alfonso $X$ en 1252, las Cortes de Segovia de 1256 y las Cortes de Valladolid de 1295 que dispusieron la necesidad de que los tributos fijados por el Monarca fueran aprobados por las propias Cortes $y$, asimismo, obligaron al Rey a moderar sus gastos para que pudiera hacerse frente a los mismos sin tener que acudir a impuestos extraordinarios.

No obstante, y a pesar de la citada mentalidad y de la mencionada idiosincrasia del siglo XIX, sí existió un régimen jurídico especial de regulación de los procedimientos concernientes a los negocios judiciales de la Real Casa. Y así, en un texto de 1855 se decía lo siguiente:

6 En este sentido, por Decreto de 14 de enero de 1875 se fijó la dotación regia en siete millones de pesetas, estableciéndose en su artículo $3 .^{\circ}$ que las pensiones de las clases pasivas de la Real Casa se abonaran en la forma prevista en el artículo $6 .^{\circ}$ de la Ley de Presupuestos de 28 de febrero de 1873 . Por su parte, la Ley de 28 de junio de 1876 determinó las dotaciones abonables al Rey y a los miembros de su familia de forma idéntica a la preceptuada en la Ley de 2 de agosto de 1886, si bien elevándose en doscientas cincuenta mil pesetas la asignación de los infantes hijos varones de Rey o de Príncipe de Asturias y reduciéndose la pensión de la Reina María Cristina a doscientas cincuenta mil pesetas. Posteriormente, las leyes de 21 de enero de 1878, 13 de noviembre de 1879 y 23 de mayo de 1906 fijaron en doscientas cincuenta mil pesetas la pensión de las Reinas Mercedes, Cristina y Victoria Eugenia, en los casos de viudedad y mientras no contrajeran segundo matrimonio, señalándose además, con respecto a las dos últimas, que mientras subsistieren sus matrimonios con los Reyes Alfonso XII y Alfonso XIII, respectivamente, contarían con la asignación anual de cuatrocientas cincuenta mil pesetas como Reinas de España. 
«... el Juez de los asuntos de la Casa Real debe ser el Juez de primera instancia del territorio. Existen así leyes que están observándose en la práctica, y los Jueces de primera instancia de Madrid están fallando todos los días los pleitos en que se litigan cuantiosos intereses de la Real Familia, siendo hoy 27 - se decía en el año 1855- los pleitos que hay pendientes" 7 .

$Y$ en este régimen jurídico peculiar de que venimos tratando, $y$ como escaso exponente del mencionado control jurisdiccional, resulta de cita obligada la sentencia del Tribunal Supremo de 28 de octubre de 1905, según la cual «la resolución ministerial declarando cuál es el concepto por el que deben tributar los servidores de la Real Casa, no es impugnable en vía contenciosa a instancia del Intendente de Palacio como representante de S.M. el Rey, que carece en este asunto de todo derecho preexistente susceptible de ser ofendido".

En lo que respecta al Derecho Constitucional Comparado, pueden resaltarse como notas informadoras de la administración de la Casa del Rey y de la dotación regia para hacer frente a la misma, las siguientes: 1.a) Todas las Monarquías europeas reconocen a la Corona una facultad de administración interna de la Casa del Rey, con plena discrecionalidad; 2.a) Esta discrecionalidad interna se articula en la práctica en la adopción de distintos sistemas organizativos, en los que suele existir la diferencia entre unidades ejecutivas de adopción de acuerdos y resoluciones para el cumplimiento de las funciones encomendadas a la Jefatura del Estado, así como unidades de carácter militar y unidades de contenido económico-financiero y contable encargadas de la gestión interna de la dotación regia y de la administración e intendencia de los medios asignados a la Casa Real; 3.a) El Parlamento interviene en la asignación de la correspondiente dotación regia para hacer frente a los gastos derivados del ejercicio de la propia Jefatura del Estado; 4.a) La mencionada dotación debe contar, desde el punto de vista jurídico-formal, con el correspondiente reflejo presupuestario; y 5.a) No existe uniformidad a la hora de precisar el ámbito temporal de la citada asignación presupuestaria, decantándose unos

7 Sobre esta cuestión, cfr. MonREAL, J. M.: Estudios histórico-legales acerca de los derechos de los Reves de España, sobre los bienes comprendidos bajo la denominación del Real Patrimonio, Madrid, 1855. 
sistemas por el criterio de la anualidad, frente al de otros ordenamientos que se inclinan por la dotación única con duración para la totalidad del reinado.

Como es sabido, la dotación que tiene asignada el Monarca recibe el nombre de lista civil, expresión ésta que procede del constitucionalismo británico, en el que la civil list contó con unas particularidades propias y específicas que la diferenciaban de las dotaciones presupuestarias con que han contado las Monarquías continentales europeas, si bien puede afirmarse que tuvo de común con éstas la importancia que desempeñó en la transformación de la monarquía patrimonial en monarquía parlamentaria, superándose así la inicial concepción del patrimonio del Rey o de la Corona con el Patrimonio y la Hacienda Pública del Estado.

A ello debe añadirse, en lo que a la Corona británica se refiere, que, como sostiene el profesor García Pelayo ${ }^{8}$, "las pretensiones del rey a tener una fuente de recursos independiente del Parlamento, y la necesidad de construir para ello una unidad patrimonial, dio lugar a la concepción de la Corona como corporation solen.

Procede, pues, detenerse en este estudio en el constitucionalismo británico. Y así es de advertir que en sus orígenes, la lista civil no abarcaba en sentido estricto la dotación personal asignada al Rey, sino que comprendía el conjunto de créditos destinados a sufragar los servicios civiles inherentes a la Administración del Estado, tales como gastos propios del personal con que contaba la Casa Real, así como los que procedían del servicio diplomático y del personal integrante del Poder Judicial, o sea, quedaban excluidos aquellos gastos que tenian carácter militar y eclesiástico.

En nuestros días, la lista civil se destina exclusivamente a sufragar los gastos oficiales derivados de las obligaciones inherentes al desempeño de la Jefatura del Estado y constituye, junto con el privy purse, las subvenciones del Parlamento para el mantenimiento de los palacios $v$ de los viajes reales, $v$ el sueldo personal para afrontar gastos privados, una de las fuentes de financiación de la Reina ${ }^{9}$.

De las anteriores fuentes de financiación, la que satisface los gastos derivados de la administración de la Casa de la Reina es la lista cipág. 29.

8 Garcia Pelayo, M.: Derecho Constitucional Comparado, Madrid, 1984,

9 Cfr., The Monarchy, Londres, 1991. 
vil, que se determina por el Tesoro -que verifica si la administración financiera de la Casa Real es eficiente- y se establece por el Parlamento. El setenta por ciento de la lista civil sirve para pagar los salarios del staff que trabaja directamente para la Reina, así como las cotizaciones a la Seguridad Social. Téngase en cuenta que dicho staff se encuentra dividido en seis departamentos, con un total de 645 empleados fijos, al frente de los cuales se encuentra el Gran Lord Chamberlain.

En lo que respecta al control de la Casa Real en el Derecho británico, señala García Pelayo ${ }^{10}$ que "es un principio de common law que el rey no puede hacer el mal, no puede realizar entuerto. No hay acción contra el rey - sino sólo un recurso de súplica-, pues los tribunales son sus tribunales, derivando en poderes de la autoridad del rey... si alguien actuando en nombre de la Corona, comete un acto ilegal, lo es por su propia responsabilidad, sin que pueda encubrirle la autorización o mandato del rey" 11 .

No obstante lo anterior, es de resaltar que hasta la Crown Procedings Act de 1947 regía sin excepción el clásico principio the King can do no wrong, en cuya virtud ningún ministro podía exigir responsabilidades al Rey por la comisión de actos ordenados por éste y ningún ciudadano podía demandar a la Corona por supuestos perjuicios ${ }^{12}$.

Esta ausencia de responsabilidad del Monarca se vio reforzada en el Reino Unido por la equiparación del término "Corona" al término "Estado" del Derecho continental. $Y$ en este sentido, el profesor Tenorio Sánchez ${ }^{13}$ recuerda que "la Corona representa la unidad de los poderes jurídico-políticos: el Poder ejecutivo es el «Rey en Consejo»; el le-

10 García Pelayo, M.: Derecho Constitucional Comparado, op. cit., pág. 296.

11 El profesor Torres del Moral alude al párrafo 61 , punto $3 .^{\circ}$, de la Carta Magna del Rey Juan, de 1215, que reconoce el derecho de resistencia en caso de delito del Rey o de sus agentes o bailios y de violación de los artículos de paz, como antecedente de la actual situación de irresponsabilidad del Rey, "concepto - como afirma el citado profesor- que comienza a elaborarse en el Continente muy poco después con la distinción entre la vis directiva y la vis coactiva del Derecho, de las cuales sólo la primera alcanza al Rey. La Monarquía moderna -añade este autor- absolutizó el poder del Rey, a lo cual respondió el Nuevo Régimen con la responsabilización de los ministros". Cfr. en este sentido Torres del Moral, A.: El príncipe de Asturias. Su Estatuto jurídico, Madrid, 1997, pág. 205.

12 El origen del citado principio, como recuerda Porras Martínez —Principio Democrático y Función Regia, Madrid, 1995, pág. 177-, se encuentra en la clásica presunción anglosajona que manifiesta que nadie puede ser más fiel cumplidor de la ley que quien la hizo.

13 Tenorio Sánchez, P. J.: Introducción al Derecho Constitucional comparado, Madrid, 1997. 
gislativo, el "Rey en Parlamento", el judicial, el "Rey en su Tribunal». Cumple, en fin - según este autor- la misión de la personalidad jurídica del Estado en el continente: se le imputan actos administrativos y judiciales; se diría que la Corona lo hace todon.

Pero desde 1947, y como escribe Papell14, upese a que el Rey sigue siendo irresponsable civil, penal y políticamente, la validez de aquel famoso principio ha sido limitada y se admite la responsabilidad de la Corona en ciertos actos administrativos..., los particulares pueden utilizar la petición de derecho contra el Rey y "la suma de dinero a la que el recurrente puede tener derecho le será pagada con los fondos que Su Majestad plazca afectar graciosamente a este efecto", según reza en el acta mencionada". $Y$ en este mismo sentido, Portero García ${ }^{15}$ indica que "el prestigio de la Corona, fundamentador de tradiciones, ha mantenido dicha irresponsabilidad o inviolabilidad de forma plena en el aspecto punitivo, aunque se encuentra paliado en otros aspectos, ya que aún no siendo factible la acción judicial contra el Rey, sino a lo sumo el recurso de súplica, los actos administrativos lesivos o los perjuicios causados por quienes actúan en nombre de la Corona admiten la demanda para la oportuna reparación o indemnización".

Una última cuestión merece destacarse de nuestro estudio de Derecho Constitucional Comparado. $Y$ es que pueden ser claros exponentes de la existencia de un supuesto control de la Administración de las Casas Regias la responsabilidad asumida por el ya citado Gran Lord Chamberlain en el Reino Unido, por el Intendant o Administrador de la lista civil en Bélgica, por el Hofofficianter o Jefe Principal de la Casa Real en Dinamarca y por el Riksmarskalken o Mariscal del Reino en Suecia.

Centrándonos ya en el estudio de lo que en nuestro Ordenamiento Constitucional denominamos "Administración Real», es de significar que de una atenta lectura del artículo 65 del Texto fundamental, son cinco las principales características que del mismo se derivan:

14 PAPELL, A.: La Monarquía española y el Derecho Constitucional europeo, Barcelona, 1980, pág. 44.

15 Portero García, L.: "La responsabilidad del Jefe del Estado", en Revista General de Derecho, n. ${ }^{\circ} 451$, pág. 468. 
1.a) La dotación presupuestaria del Rey, a diferencia del sistema empleado en nuestras Constituciones del siglo XIX, así como de la técnica utilizada por los textos constitucionales belga y danés, no se fija al principio de su reinado, sino con periodicidad anual en los diferentes Presupuestos Generales del Estado.

2. a) La mencionada dotación tiene carácter global y, en consecuencia, no se concreta en partidas determinadas.

3.a) La cantidad incluida a favor del Rey se administra y se distribuye por éste libremente.

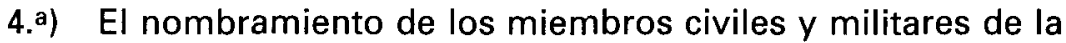
Casa del Rey es un acto que se ejerce libremente por el Rey, Y

5. a) El citado acto de nombramiento no está sujeto de forma preceptiva al régimen jurídico del refrendo, establecido en el artículo 64 del Texto fundamental.

Se constitucionaliza así la Casa del Rey como institución administrativa al servicio de la Corona, cuya regulación - como tal institución administrativa-, y según apunta la profesora García-Atance ${ }^{16}$, «podría conducir a la conclusión de que es una institución poco relevante $y$ de escaso interés dentro del ámbito de la Corona; sin embargo, hay una serie de consideraciones que hacen rectificar esa primera impresión", consideraciones éstas de las que vamos a tener ocasión de tratar a propósito de la extensión y límites de las funciones administrativas del Rey, así como del posible control de la Administración de la propia Casa del Rey.

Entre las funciones de la Administración de la Casa del Rey puede hacerse mención de las siguientes:

1. a) La regulación de los servicios de gestión de personal de la Casa del Rey, en el particular relativo a nombramientos, ceses, adscripciones, provisiones de puestos de trabajo, reconocimientos de derechos, ejercicio de la potestad sancionadora y resolución de recursos y reclamaciones.

2.a) La organización de los servicios de infraestructura material, relativos al ejercicio de las funciones que corresponden a la Jefatura del Estado.

16 Garcia-Atance y Garcia de la Mora, M. V.: “Bienes estatales al servicio de la Corona", en Estudios sobre la Monarquía, coordinados por Torres del Moral, A. y Gómez Sánchez, Y., Madrid, 1995, pág. 305. 
3.a) La realización efectiva de cuantas actuaciones debe llevar a cabo el Rey en sus relaciones con organismos oficiales y demás actuaciones derivadas del ejercicio de las funciones simbólicas y representativas que tiene encomendadas.

4. a) El desempeño de funciones derivadas de régimen interior de la servidumbre de la Familia Real.

5. a) La gestión económica y presupuestaria de los gastos derivados de las anteriores funciones, tales como contratación administrativa, ordenación de pagos, planificación financiera y ejecución presupuestaria.

Desde nuestro punto de vista, las anteriores funciones evidencian, de un lado, la amplia autonomía de que goza la Corona para la gestión y distribución de la dotación presupuestaria con que cuenta - autonomía ésta, por lo demás, garantizada constitucionalmente- $y$, de otro, que las citadas funciones administrativas conllevan una actividad de organización de los servicios de la Casa del Rey, de nombramiento de diverso personal y de regulación de cuestiones concretas derivadas de dicha gestión que, forzosamente, han de traducirse en la adopción de una serie de actos concretos - a nuestro entender, de inequívoca naturaleza administrativa-, tales como nombramientos y ceses, y también la adopción de normas internas de funcionamiento -en nuestra opinión también de carácter administrativo-, que no son sino ejemplos de una potestad reglamentaria o, si se prefiere, de carácter normativo, que necesariamente ha de residenciarse en la propia Casa del Rey para la adecuada organización de sus servicios internos, así como para su correcto funcionamiento.

No se diga, en contra de la tesis que aquí propugnamos, que la aludida potestad reglamentaria es competencia exclusiva y excluyente del Gobierno y de las Administraciones Públicas General, Autonómica, Local e Institucional y que, fuera de las mismas, no cabe aceptar el ejercicio de dicha potestad, pues, a nuestro juicio, $y$ aunque es cierto que el artículo 97 de la Constitución determina que el Gobierno ejerce la potestad reglamentaria, son varios los órganos constitucionales y de relevancia constitucional, así como distintas instituciones públicas, que sin tener el carácter de Administración Pública en sentido estricto, desempeñan, como hemos visto, funciones de naturaleza administrativa y cuentan con atribuciones de autorregulación, mediante la elaboración y aprobación de normas de carácter reglamentario, existiendo, a 
este respecto, diversos preceptos en nuestro Ordenamiento que dan buena prueba de ello17.

Así, y aunque autores como el profesor Díez Picazo ${ }^{18}$ advierten que la relevancia jurídica y extrajurídica de la Casa del Rey "es esencialmente interna", no puede desconocerse, como reconoce dicho autor, que se trata de un aparato administrativo que administra un órgano constitucional: la Corona. $Y$ es evidente, a nuestro modo de ver, que esa administración debe concretarse tanto en actuaciones singulares, como en actuaciones de carácter general, ambas de indiscutible naturaleza jurídico-administrativa.

Por lo demás, no debe olvidarse que la vigente regulación de la Casa del Rey, contenida en el Real Decreto 434/1988, de 6 de mayo, atribuye a la misma, en el artículo $1 .^{\circ} 2$, el desempeño de cometidos de carácter administrativo y económico, siendo elocuente, en este orden de ideas, el preámbulo de dicha norma, cuando advierte en su párrafo $1 .^{\circ}$ que "la Casa de S.M. el Rey, aun sin estar integrada en la Administración del Estado, debe aplicarse a su organización y funcionamiento determinados principios y criterios" de la propia Administración Pública.

La Casa del Rey constituye, pues, una Administración Medial -de acuerdo con la terminología utilizada al respecto por estudiosos de la Ciencia de la Administración-19, en el sentido de que tanto su naturaleza como su finalidad y fundamento se concretan en su carácter de servicio y de apoyo al órgano en el que se encuentra incardinada -en nuestro caso, la Jefatura del Estado- y en la ausencia de finalidades generales y directas al servicio de los ciudadanos, a diferencia de lo que sucede con las Administraciones Públicas de base territorial e institucional.

17 Es el caso, entre otros, de los artículos 10.j de la Ley Orgánica 2/1979, de 3 de octubre, del Tribunal Constitucional; 107.9 y 110 de la Ley Orgánica 6/1985, de 1 de julio, del Poder Judicial; 3.f) y g) y disposición final segunda de la Ley 7/1988, de 5 de abril, de Funcionamiento del Tribunal de Cuentas; y 34 de la Ley Orgánica 3/1981, de 6 de abril, del Defensor del Pueblo.

18 Diez PICAzo, L. M.: «El Régimen Jurídico de la Casa del Rey (un comentario al artículo 65 de la Constitución)", en Revista Española de Derecho Constitucional, 1982, n. ${ }^{\circ} 6$, pág. 128.

19 Cfr., en este aspecto, Baena del Alcázar, M.: Curso de Ciencia de la Administración, Madrid, 1985, pág. 196, y CANALEs AlIende, J. M.: "La Administración del Tribunal de Cuentas en su nueva Ley de Funcionamiento", en Actualidad Administrativa, 1990, nos 1 y 2. 
En esta organización que estamos analizando $0^{20}$, particular importancia tiene la figura del Jefe de la Casa del Rey. Se trata, como Director que es de la Administración Real, del máximo responsable jurídico de la actuación administrativa en que se articula la Casa del Rey, con todo lo que eso comporta de cara a la eficacia jurídica de su actuación. Es, en palabras del profesor Cremades21, "la figura central de esta "organización", lo que fácilmente se acredita con la sola lectura de sus competencias".

Así, el ejercicio de competencias tales como la dirección e inspección de los servicios de la Casa del Rey, la realización del presupuesto de la misma, la disposición de los gastos propios de los servicios de la Casa, la firma de los contratos referentes a materias propias de la Casa Regia y la elaboración de normas de organización, régimen interior y coordinación de las unidades que dependen del Jefe de la Casa del Rey, conlleva inequívocamente la adopción de actos objetivamente administrativos $y$, por tanto, susceptibles de ulterior fiscalización jurisdiccional.

Por lo demás, no debe olvidarse que la vigente regulación de la Casa del Rey, contenida en el Real Decreto 434/1988, de 6 de mayo, atribuye a la misma, en el artículo $1 .^{\circ}-2$, el desempeño de cometidos de carácter administrativo y económico, siendo elocuente, en este orden de ideas, el preámbulo de dicha norma, cuando advierte en su párrafo $1 .^{\circ}$ que "la Casa de S.M. el Rey, aun sin estar integrada en la Administración del Estado, debe aplicarse a su organización y funcionamiento determinados principios y criterios" de la propia Administración Pública.

20 La Casa del Rey se creó por el Decreto 2942/1975, de 25 de noviembre, a raíz de la proclamación del entonces Príncipe como Rey de España, unificándose en ella las Casas Civil y Militar del anterior Jefe del Estado. Posteriormente, la Casa del Rey se reorganizó por el Real Decreto 310/1979, de 13 de febrero, que estableció las siguientes unidades: Jefatura, Cuarto Militar, Secretaría General, Guardia Real y Servicio de Seguridad. La vigente organización de la Casa del Rey se encuentra en el aludido Real Decreto 434/1988, de 6 de mayo. Según establece el artículo $2 .^{\circ}$ de esta disposición, la Casa del Rey se organiza en una Jefatura, la Secretaría General, el Cuarto Militar y la Guardia Real y, por último, el Servicio de Seguridad. Mediante Real Decreto 657/1990, de 25 de mayo, se crea, dependiendo directamente de la Jefatura de la Casa Real, una Oficina con cometidos de apoyo y de asistencia inmediata. Al frente de la misma existe un Jefe, que tiene la consideración de personal de dirección, y está compuesta de un máximo de cinco miembros, como personal técnico de asesoramiento.

21 Cremades Garcia, J.: La Casa de S.M. el Rey, Madrid, 1998, pág. 62. 
Desde las precedentes consideraciones es claro que la figura del Jefe de la Casa del Rey, al situarse como máximo responsable jurídico de la misma, asume su personalidad jurídica, que es tanto como decir que ejerce su representación y ostenta legitimación procesal en relación con posibles supuestos de control jurisdiccional de actos jurídicos procedentes de la propia Casa del Rey.

En atención al status jurídico del Jefe de la Casa del Rey, nos planteamos aquí una trascendental cuestión, y es la posibilidad y conveniencia de que la Jefatura de la Casa Regia refrende todos los actos del Rey de administración interna de su Casa y de nombramiento de sus miembros.

Frente a nuestra opinión se puede argumentar que dicha posibilidad carece de cobertura constitucional, pues el artículo 64.1 de la Norma fundamental no contempla esta posibilidad y, además, el artículo 65 atribuye al Rey facultades de libre distribución de la dotación regia y de libre nombramiento de los miembros civiles y militares de la $\mathrm{Ca}$ sa del Rey.

Sin embargo, entendemos, de un lado, que el contenido del expresado artículo 64.1 no implica un numerus clausus, pues puede darse el caso de que actos distintos de los enumerados en ese precepto puedan ser refrendados por diferentes personas de las allí indicadas, al estimarse que una interpretación extensiva del artículo 64.2 conduce a defender este criterio, por no existir una prohibición expresa de refrendo de los actos tipificados en el artículo $65 ; y$, de otra parte, somos de la opinión que ese grado de libertad que la Constitución otorga en este punto al Monarca no impide, en adecuada interpretación del Texto constitucional como consecuencia de su directo valor normativo, la traslación de la posible responsabilidad derivada de dichos actos a la figura del Jefe de la Casa del Rey. De todo ello nos ocuparemos en posteriores líneas, a propósito de la consideración de lege ferenda que propugnamos sobre la promulgación de un Estatuto de la Casa del Rey, articulándose así en este ámbito de actuación de la propia Casa Regia el refrendo como «acto de naturaleza compleja", en expresión utilizada por el profesor Lafuente $^{22}$ a propósito del estudio de la práctica del mando militar por parte del Rey.

22 Lafuente Balle, J. M.: "De cómo opera en la práctica el mando militar del Rey", en Revista de Derecho Político, n. ${ }^{\circ}$ 36, Madrid, 1992, pág. 321. 
Por otro lado, en la apuntada concepción del Jefe de la Casa Regia como máximo responsable de la Administración Real particular importancia tiene la figura del Secretario General, que en sus funciones de apoyo y asesoramiento a dicha Jefatura va a desempeñar un auténtico papel de órgano staff and line ${ }^{23}$, de igual forma que el Jefe de la Oficina de apoyo y asistencia inmediata a la Jefatura de la Casa, que asimismo presta servicios propios de ese tipo de órganos ${ }^{24}$.

En resumen, la argumentación que de contrario cabe objetar a nuestra tesis puede ser doble: de un lado, sostener que el principio de inviolabilidad regia impide admitir el control jurisdiccional de la Casa del Rey; $y$, de otro, entender que la libertad de actuación que el artículo 65 otorga al Monarca en la organización de su Casa, así como el carácter doméstico y no jurídico de esa misma actuación, hace inoperante la existencia de cualquier tipo de fiscalización jurisdiccional.

Sin embargo, y a nuestro modo de ver, las dos objeciones apuntadas pueden rebatirse por las siguientes razones:

En primer lugar, porque la inviolabilidad y consiguiente irresponsabilidad del Rey no deben impedir el que un órgano administrativo al servicio de la Corona, como es la Casa del Rey, pueda ser controlado jurisdiccionalmente en su actuación de naturaleza jurídica.

En segundo término, porque la libertad de actuación del Monarca en la organización de su Casa no debe significar inexistencia de control con respecto, no a esa misma actuación libre o, en términos jurídicos más precisos, discrecional, sino a los actos separables o, si se prefiere, a los actos jurídicos en que se materializa tal actuación del Rey, por medio de disposiciones y actos concretos y específicos.

23 Sobre los antecedentes y el significado de los órganos staff and line, cfr. URWICK, L.: "Organization as a technical problem", en Papers on the science of Administration; Gulick, L. y URWICK, L., Nueva York, 1937, pág. 57, y Paramés MonteneGRo, C.: Introducción al Management. Un nuevo enfoque de la Administración Pública, Madrid, 1974, pág. 89.

24 Los estudiosos de la organización administrativa y de la Ciencia de la Administración han otorgado especial trascendencia a los órganos staff and line, por su directa repercusión en el proceso de toma de decisiones y por su concreta eficacia jurídica en la voluntad del órgano decisor. El legislador se ocupó de estos órganos, entre otros, en el artículo 19 de la antigua Ley de Régimen Jurídico de la Administración del Estado. En la actualidad, el artículo 17.1 in fine de la Ley 6/1997, de 14 de abril, dè Organización y Funcionamiento de la Administración General del Estado, atribuye a los Secretarios Generales Técnicos competencias en materia de producción normativa y asistencia jurídica. 
En tercer lugar, porque aunque esa libertad de actuación se articula en una inexistencia de refrendo, tal circunstancia no sólo no debe significar ausencia de control, sino que ha de reforzar, a los efectos de precisar su régimen de juridicidad, un sistema de control personificado en la figura del Jefe de la Casa del Rey.

En cuarto término, porque el referido carácter doméstico no debe ser incompatible con la producción de concretas consecuencias jurídicas, si tenemos en cuenta, como debe tenerse presente, que nos estamos refiriendo a actos de naturaleza jurídico-administrativa y sometidos al Derecho Administrativo.

$Y$, en fin, porque los mencionados actos pueden afectar, como de hecho afectan, a situaciones jurídicas individualizadas que, ante una eventual inexistencia de control jurisdiccional, quedarían inmersas en un contexto de indefensión opuesto a las prescripciones constitucionales habidas sobre el particular, propias de un Estado de Derecho.

Consecuentemente, la expresada libertad de actuación no debe suponer inexistencia de control jurisdiccional, como se infiere de la sentencia de la Sala de lo Contencioso-Administrativo del Tribunal Supremo, de 28 de enero de 1995, a cuyo tenor "el reconocimiento del amplio rango que la Ley concede a la actividad discrecional de la Administración... no significa la consagración de zonas inmunes al control jurisdiccional, ya que la discrecionalidad viene siempre atemperada por elementos reglados que configuran su perfil y generalmente se concretan en la respectiva verificación de la competencia del órgano decisivo, la observación del procedimiento legalmente establecido y la explicación del fin perseguido".

Así pues, la reseñada libertad de actuación, constitucionalmente garantizada por el artículo 65 del Texto fundamental, no debe hacernos pensar que el Rey sea el administrador material de su Casa -como hemos señalado, es el Jefe de la Casa del Rey quien, realmente, desempeña, como tal Jefe, la dirección de la Administración de dicha Casa-, ni debe tampoco fundamentar la posible y, en nuestra opinión, indebida inexistencia de control jurisdiccional. «En un Estado de Derecho -escribe el profesor González Pérez ${ }^{25}$ - es inconcebible cualquier exclusión en razón de la materia o en razón de la persona. Ni materias excluidas ni personas inmunes al control judicial. Todo acto sujeto al Or-

25 GonzÁlez Pérez, J.: «El control jurisdiccional de los actos del Jefe del Estado", en Estudios sobre la Constitución Española, VV.AA., 1991, pág. 1990. 
denamiento jurídico, toda actividad ordenada por el Derecho, está sujeto al control de los Jueces y Tribunales".

En otro aspecto, debe destacarse que la aplicación del derecho a la tutela judicial efectiva a todos los poderes públicos implica que, desde nuestro punto de vista, no pueda excluirse de la actuación concreta de los mismos el mandato contenido en el artículo 24 del Texto fundamental; por lo que, conforme a ese punto de vista, no es constitucionalmente asumible defender que dicho precepto no es aplicable a la actuación jurídico-administrativa desempeñada por el aparato burocrático-administrativo incardinado en la Casa del Rey.

Somos conscientes de que, de contrario, se puede argumentar que la Corona no es un poder público o que, en otros términos, no es un órgano constitucional. No compartimos, sin embargo, dicho planteamiento, pues, de entrada, es preciso admitir que toda la actuación del Monarca -incluida la de carácter privado y la de índole interna de organización y gestión de su Casa- cuenta con una indiscutible proyección pública.

Como ha puntualizado el profesor Torres del Moral26, "es vana la pretensión de identificar una esfera o vida privada del Monarca. El Rey es Rey trescientos sesenta y cinco días del año y veinticuatro horas diarias. Nada en él ni en su familia es ajeno a los intereses del Estado" y, por extensión, nada en la Casa del Rey debe ser tampoco ajeno a los intereses públicos.

Partiendo de la concepción de órgano constitucional del profesor García Pelayo27, como "órgano directamente establecido y estructurado por la Constitución", es claro que la Corona tiene ese carácter. Escribe así la profesora Fernández Miranda ${ }^{28}$ que "la Corona - denominación específica de un órgano constitucional, la Jefatura del Estado-precisa el desarrollo en su seno de una actividad administrativa al ser-

26 Torres del Moral, A.: Principios de Derecho Constitucional español, Madrid, 1998, pág. 519.

27 Garcia Pelayo, M.: "El "status" del Tribunal Constitucional», en Revista Española de Derecho Constitucional, 1981, n. ${ }^{\circ}$ 1, pág. 12.

28 Fernández-Miranda Campoamor, C.: "La dotación de la Corona. La Casa del Rey", en Estudios sobre la Monarquia, op. cit., pág. 228. 
vicio de las competencias constitucionales que le han sido encomendadas".

En idéntico sentido se pronuncia el profesor Bassols Coma ${ }^{29}$, cuando sostiene que "la Corona es un órgano constitucional - de naturaleza especial respecto a los demás órganos constitucionales- y que al igual que éstos, requiere una apoyatura administrativa autónoma para el cumplimiento de sus funciones constitucionales". Igualmente, el profesor Guaita ${ }^{30}$ se muestra partidario de considerar a la Corona y, más concretamente, a la Casa del Rey como un poder público.

$Y$ a fin de determinar la jurisdicción competente para el control de la actuación administrativa de la Casa del Rey es preciso señalar que de lege lata son dos las soluciones que pueden barajarse: de un lado, y con apoyatura en el artículo $66^{31}$ de la Ley Orgánica 6/1985, de 1 de julio, del Poder Judicial, interpretar que debe ser la Sala de lo Contencioso-Administrativo de la Audiencia Nacional la competente para proceder al enjuiciamiento de la actuación administrativa que nos ocupa; $y$, de otro, $y$ con base en el artículo 74.1.j) ${ }^{32}$ de la expresada Ley, dedu-

29 Bassols COMA, M.: "Instituciones Administrativas al servicio de la Corona: dotación, Casa de S.M. el Rey y Patrimonio Nacional", en Revista de Administración Pública, Madrid, 1983, nos 100-102, pág. 892.

30 Guaita Martorell, A.: "Las "otras" Administraciones del Estado», en Gobierno y Administración en la Constitución, VV.AA., Madrid, 1988, vol. I, pág. 869.

${ }_{31}$ Según este precepto, redactado conforme a la Ley Orgánica 6/1998, de 13 de julio, de reforma de la citada Ley del Poder Judicial, "la Sala de lo Contencioso-Administrativo de la Audiencia Nacional conocerá en única instancia de los recursos contra disposiciones y actos de los Ministros y Secretarios de Estado que la Ley no atribuya a los Juzgados Centrales de lo Contencioso-Administrativo...".

En el mismo sentido se expresa el artículo 11.1.a) de la nueva Ley Reguladora de la Jurisdicción Contencioso-Administrativa, de 13 de julio de 1998, que asigna a dicha Sala el conocimiento "de los recursos que se deduzcan en relación con las disposiciones generales y los actos de los Ministros y de los Secretarios de Estado en general y en materia de personal cuando se refieran al nacimiento o extinción de la relación de servicio de funcionarios de carrera. Asimismo, conocerá de los recursos contra los actos de cualesquiera órganos Centrales del Ministerio de Defensa referidos a ascensos, orden y antigüedad en el escalofonamiento y destinos".

32 Conforme a lo dispuesto en este artículo, redactado de acuerdo con la mencionada Ley Orgánica 6/1998, "las Salas de lo Contencioso-Administrativo de los Tribunales Superiores de Justicia conocerán en única instancia... de los recursos que se deduzcan en relación con cualesquiera otras actuaciones administrativas no atribuidas expresamente a la competencia de otros órganos de este orden jurisdiccional".

En idéntico sentido se pronuncia el artículo 10.1.j) de la nueva Ley de la Jurisdicción Contencioso-Administrativa, de 1998, que atribuye a las Salas de lo Con- 
cir que la Sala de lo Contencioso-Administrativo del Tribunal Superior de Justicia correspondiente es la que tiene competencia para realizar el aludido control jurisdiccional.

De las dos soluciones propuestas, la primera tiene como principal inconveniente que, desde el punto de vista del titular de la Administración autora del acto impugnado - el Jefe de la Casa del Rey-, éste no es, en sentido estricto, ni Ministro ni Secretario de Estado, y ello a pesar de que esté equiparado a éstos atendiendo a su rango jerárquico y a su régimen retributivo; por lo que, desde el precitado punto de vista jurídico-formal, la Sala jurisdiccional de la Audiencia Nacional podría declararse incompetente para conocer de las impugnaciones de referencia.

En cambio, no sucedería así con las Salas de lo Contencioso-Administrativo de los Tribunales Superiores de Justicia, que en virtud de la competencia residual contenida en el indicado artículo 74.1.j) de la Ley Orgánica Judicial vendrian obligadas a conocer de los recursos contra la actuación administrativa que estamos comentando ${ }^{33}$.

De lege ferenda, sin embargo, entendemos que lo más procedente es residenciar las impugnaciones promovidas contra las disposiciones y actos emanados del Jefe de la Casa del Rey en el ejercicio de las funciones administrativas que tiene encomendadas, en la Sala de lo Contencioso-Administrativo del Tribunal Supremo, como sucede con los restantes órganos constitucionales en materia de personal, régimen interior y gestión patrimonia|34.

tencioso de los Tribunales Superiores de Justicia el conocimiento de los recursos contra "cualesquiera otras actuaciones administrativas no atribuidas expresamente a la competencia de otros órganos de este orden jurisdiccional».

33 El Tribunal Supremo, en sentencia de la Sección 7.a de la Sala Tercera de fecha 8 de julio de 1996, resolvió la cuestión de competencia suscitada entre la Sala de lo Contencioso-Administrativo del Tribunal Superior de Justicia de Madrid, en su Sección 4. ${ }^{a}$ y la Sección 5. ${ }^{a}$ de la Audiencia Nacional, en un recurso deducido por personal militar al servicio de la Casa del Rey, impugnando resoluciones del Jefe del Cuarto Militar de dicha Casa sobre rectificación de antigüedad y ascensos del citado personal militar. $Y$ lo hizo declarando que la competencia para conocer del expresado recurso correspondía a la Audiencia Nacional.

34 Cfr., en este aspecto, el artículo $58.1 .^{\circ}$ de la Ley Orgánica del Poder Judicial, que determina que "la Sala de lo Contencioso-Administrativo del Tribunal Supremo conocerá... en única instancia de los recursos contencioso-administrativos que se promuevan contra actos y disposiciones del Consejo de Ministros, de las Comisiones Delegadas del Gobierno, y del Consejo General del Poder Judicial y contra los actos y disposiciones de los órganos competentes del Congreso de los Diputados y del Senado, del Tribunal Constitucional, del Tribunal de Cuentas y del 
Finalmente, fundamentamos también nuestra tesis del control jurisdiccional de la actuación administrativa de la Casa del Rey en la sentencia del Tribunal Constitucional de 28 de noviembre de 1984, que expresamente admite y contempla esa posibilidad. Y así, del contenido de los fundamentos jurídicos de esta sentencia pueden destacarse las siguientes consideraciones:

- Aunque el artículo 43 de la Ley Orgánica del Tribunal Constitucional se ocupa de las vulneraciones referidas al Ejecutivo, y, en general, de las Administraciones Públicas, tanto en sus manifestaciones territoriales como en las institucionales y corporativas, y podría decirse, en el caso de este recurso, que el acto que se acusa como lesivo del principio de igualdad tiene su origen en una decisión de la Jefatura de la Guardia Real, debe entenderse que ésta se encuentra comprendida en la organización de la Casa del Rey, que es una organización estatal, pero que no se inserta en ninguna de las Administraciones Públicas.

- La nítida separación de la organización de la Casa del Rey respecto de las Administraciones Públicas, con fundamento constitucional en el artículo 65 de la Constitución, y lo que esto comporta respecto a la independencia que debe rodear a la gestión de dicha Casa, admite una regulación del estatuto jurídico del personal de la Casa.

- Los actos que en aplicación de esa regulación procedan de los órganos a los que se encomienda la gestión pueden someterse al control jurisdiccional, a través de la vía contencioso-administrativa, $y$, en el caso de que se acuse la violación de un derecho o libertad fundamental, tengan acceso al recurso de amparo constitucional.

Y en apoyo también de nuestra tesis, la promulgación de la nueva Ley de la Jurisdicción Contencioso-Administrativa ${ }^{35}$ ha reforzado esta idea que hemos comentado de plenitud de control jurisdiccional, pues, como dice Sainz de Robles ${ }^{36}$, con dicha Ley "ha quedado en claro que no hay ninguna actuación de la Administración inmune a la fis-

Defensor del Pueblo en los términos y materias que la Ley establezca y de aquellos otros recursos que excepcionalmente le atribuya la Ley".

35 Sobre la incidencia de la citada Ley de 13 de julio de 1998 en la concepción del contencioso-administrativo como instrumento garantizador de los derechos fundamentales y como técnica de control jurisdiccional de toda actuación de los poderes públicos sujeta a Derecho Administrativo, cfr. Del Cacho Frago, A. y Vacas García-Alós, L.: Comentarios a la Ley de la Jurisdicción Contencioso-Administrativa, Madrid, 1998, pág. 9.

36 SAINZ DE ROBLES, F. C.: «Comentarios a la Ley 29/1998 de 13 de julio, reguladora de la Jurisdicción Contencioso-Administrativa", en La Ley, 1998, n. 4637. 
calización judicial, al alcanzar rango constitucional (y supranacional) la cláusula de garantía contra los actos de los poderes públicos sujetos a Derecho Administrativo; de todos los poderes, digo, y no sólo de la Administraciones Públicas».

\section{VI}

Por otra parte, y juntamente con el apuntado control contencioso-administrativo de la actuación administrativa de la Casa del Rey, y teniendo en cuenta, de un lado, que los fondos que maneja la Casa del Rey son de naturaleza jurídico-pública, $y$, de otro, que dicha Casa no es sino una institución administrativa o, si se prefiere, una organización estatal al servicio de la Corona, no ofrece duda, a nuestro juicio, que la gestión económico-financiera, presupuestaria y contable que lleva a efecto el Jefe de la propia Casa del Rey no puede estar exenta del control jurisdiccional contable, como función jurisdiccional constitucionalmente reconocida al Tribunal de Cuentas ${ }^{37}$.

37 Cfr., en este sentido, Vacas Garcia-Alós, L.: El Tribunal de Cuentas - Enjuiciamiento contable y jurisprudencia constitucional, Madrid, 1998.

La existencia de una específica función jurisdiccional contable no es exclusiva del Ordenamiento jurídico español, pues en países como Francia, Italia, Grecia y Portugal las Cortes de Cuentas realizan cometidos de control jurisdiccional. Sirvan de ejemplo, en este sentido, los artículos 100 y siguientes de la Constitución italiana de 1947, en los que se contempla una función jurisdiccional dirigida a los que manejan, de una u otra forma, fondos públicos $y$ orientada al enjuiciamiento de los funcionarios que, al violar deberes inherentes a sus respectivos cargos, causen daños al erario público. De esta forma, en nuestro Ordenamiento la función jurisdiccional del Tribunal de Cuentas tiene cabida en el llamado modelo latino, integrado por países como, además de los citados, Bélgica, en los que el órgano de control externo tiene carácter colegiado con cometidos de carácter jurisdiccional. Otros modelos son el anglosajón, compuesto por Estados Unidos, el Reino Unido, Irlanda e Israel, en los que existe un órgano monocrático designado por el Parlamento y por el Jefe del Estado, que depende del propio Parlamento, al que dirige los resultados de sus funciones fiscalizadoras y asesoras, y que cuenta con una plena independencia funcional; el germánico, formado por Alemania y Austria, en donde existe un órgano monocrático de dirección, designado por el Parlamento y por la Jefatura del Estado, con estructura colegiada —en el caso de Alemania-, y con funciones fiscalizadoras a posteriori y de carácter consultivo, tanto respecto del Legislativo, a quien eleva sus informes, como del Ejecutivo; y el modelo escandinavo, en el que el órgano de control depende del Ejecutivo y realiza funciones fiscalizadoras a posteriori y también funciones de asesoramiento del Gobierno y no del Parlamento. Cfr., en este sentido, MuÑoz Álvarez, R.: "Reflexiones sobre la situación actual de control", en Jornadas sobre la Intervención y el control de los gastos públicos de las Comunidades Autónomas, Valladolid, 1994. 
Por consiguiente, actuaciones tales como la ordenación de pagos, el cumplimiento contractual de la gestión financiera inherente a una determinada contratación de medios materiales, la habilitación de medios personales, la gestión económica derivada del régimen interior, la programación y ejecución presupuestaria $y$, en general, cualesquiera otras conducentes a la dirección, coordinación y gestión de los servicios económicos, son cuestiones que por su significado y por su naturaleza no pueden sustraerse de la función fiscalizadora del Tribunal de Cuentas, de igual modo que sucede con otra institución administrativa al servicio de la Corona, como es el Patrimonio Nacional.

En consecuencia, debe tenerse presente en primer lugar, que la procedencia de los fondos de la Casa del Rey, así como su concreta asignación en los Presupuestos Generales del Estado y los específicos intereses públicos a los que están afectos -íntimamente ligados a la Jefatura del Estado-, demuestran la inequívoca naturaleza jurídicopública de dichos fondos; $y$, en segundo término, que siendo, como es, la Casa del Rey una organización estatal y, por ende, perteneciente al sector público, esto es, al Estado en sentido amplio, carecería de sentido defender que la gestión económico-financiera de la misma podría llevarse a efecto de manera distinta a la contemplada en este aspecto por la normativa presupuestaria y contable. El contenido de preceptos tales como los artículos $7 .^{\circ}, 10,14,17$ a 20, 48 y siguientes, 74.1, 75, 77, $78.1,92,122$ y 140 y siguientes de la Ley General Presupuestaria, así como los artículos $1 .{ }^{\circ} 1,2^{\circ}, 9 .^{\circ} 1,11,15.1$ y 38.1 de la Ley Orgánica del Tribunal de Cuentas, y 27.1, 31 y 49.1 de la Ley de Funcionamiento del propio Tribunal de Cuentas, constituye buena prueba de lo que aquí se propugna.

Por lo demás, es preciso tener presente que una de las notas características de que los fondos de la Casa del Rey son de naturaleza pública es que tienen procedencia del sector público, en el sentido de que cuentan con una dotación y un tratamiento presupuestario públicos. Las Leyes de Presupuestos Generales del Estado para los distintos ejercicios económicos dan buena prueba de ello. $Y$ es que, como pone de relieve Rodríguez Bereijo ${ }^{38}$, el artículo 65 de la Constitución implica los siguientes efectos:

38 Rodriguez Bereijo, A.: «La Ley de Presupuestos en la Constitución Española de 1978", en La Hacienda Pública en la Constitución Española, VV.AA., Madrid, 1979, pág. 207. 
- «Inclusión obligatoria en los Presupuestos de cada año de la dotación presupuestaria de la Corona. Las Cortes pueden discutir la cantidad global, pero no pueden negarse a su aprobación.

- La consignación presupuestaria de la "lista civil" constituye un crédito global que no aparece distribuido con detalle y especificado en la Ley del Presupuesto, lo que significa atribución al Rey de la facultad para fijar libre y discrecionalmente su destino específico.

- La dotación presupuestaria, consustancial con la institución de la Corona y con la forma política monárquica del Estado, no puede suprimirse."

Así, y a modo ilustrativo, no está de más indicar que en la Ley 41/1994, de 30 de diciembre, de Presupuestos Generales del Estado para 1995, así como en la Ley 12/1996, de 30 de diciembre, de Presupuestos Generales del Estado para 1997, en la Ley 65/1997, de 30 de diciembre, de Presupuestos Generales del Estado para 1998; en la Ley 49/1998, de 30 de diciembre, de Presupuestos Generales del Estado para 1999, y, finalmente, en la Ley 54/1999, de 29 de diciembre, de Presupuestos Generales del Estado para el año 2000, además de presupuestarse un programa genérico denominado "Alta Dirección del Estado y del Gobierno", se determina como primer programa, dentro de la distribución de los créditos por programas, el de "Jefatura del Estado".

\section{VII}

Los argumentos esgrimidos a lo largo del presente estudio en favor de nuestra tesis, de plenitud de ese control jurisdiccional, han evidenciado también otra realidad igualmente incuestionable: la necesidad insoslayable de que la Casa del Rey cuente con un Estatuto, similar al que tienen otros órganos constitucionales.

De contrario puede esgrimirse que no resulta necesario el otorgamiento de rango legal al Estatuto que aquí propugnamos, por considerar que es suficiente la regulación de este particular por medio de un Real Decreto.

A este respecto, Cremades García ${ }^{39}$ pone de manifiesto que "si la Casa de S.M. el Rey y las decisiones con respecto a reestructuraciones y nombramientos hubieran sido reguladas por ley, la voluntad y los deseos del Monarca hubieran tenido que ceder ante los superiores, por soberanos, del Parlamento. El tradicional proceso deliberativo de éste 
y el régimen de opinión pública propio de las democracias que impera en nuestro país hubiera posibilitado en los obligados debates, voces discrepantes en materia tan necesitada de consenso e incluso de unanimidad como ésta. De este modo - señala el expresado autor-, con el uso del Real Decreto, se evita extender innecesariamente las legítimas discrepancias que al respecto pueden existir entre las distintas fuerzas políticas e incluso entre la propia Jefatura del Estado y éstas".

Sin embargo, en nuestra opinión el marco legal que defendemos no sólo es el adecuado por razón de la materia y en atención a un principio de igualdad jurídica con respecto a otros órganos constitucionales, sino que, además, no supone cesión de ninguna clase con respecto al Legislativo, ni tiene porqué afectar a las relaciones de la Jefatura del Estado con las fuerzas políticas en la representación que éstas ostentan dentro de la cotidiana actividad del Parlamento.

Y es lo cierto, además, que, en el contexto de la Monarquía parlamentaria, el Estatuto de rango legal que defendemos se ajusta mejor a sus postulados que el simple Real Decreto. Diríase, por consiguiente, que ni la Corona merece ese tratamiento, ni una Monarquía parlamentaria debe hacer compatible su verdadero significado con una situación normativa como la todavía vigente.

Demandamos, pues, como de imperiosa necesidad la promulgación de un Estatuto de la Casa del Rey que, con el debido rango normativo, dé respuesta a cuantos aspectos puedan plantearse con respecto a la organización y al funcionamiento de la misma.

Resulta, por tanto, realmente sorprendente que el órgano estatal al servicio de la Corona, habiendo transcurrido más de veinte años después de promulgada la Constitución, carezca de un Estatuto de rango legal y que, como consecuencia de ello, la Casa del Rey tenga que seguir acomodando su actuación a una disposición reglamentaria dictada por el Ejecutivo.

En este sentido, la estructura y contenido del Estatuto propuesto de la Casa del Rey, podría girar alrededor de ocho líneas básicas de articulación jurídica de ese contenido:

- Del ámbito de aplicación del Estatuto de la Casa del Rey.

- De las funciones de la Casa del Rey, que podrían sistematizarse asi: funciones institucionales y protocolarias, funciones jurídicoadministrativas de organización y de gestión interna de los servicios, y funciones de gestión económico-financiera, presupuestaria y contable.

- Del régimen jurídico de la actuación de la Casa del Rey, con especial consideración de la impugnación de los acuerdos y disposi- 
ciones de la administración y gestión interna de la Jefatura de la Casa del Rey y de la Junta de Gobierno de la misma, y con referencia también al régimen del refrendo de tales acuerdos y disposiciones.

- De la organización de la Casa del Rey, dando cabida en esa estructura organizativa a la Jefatura de la Casa Regia juntamente, en su caso, con la Jefatura de la Casa del Príncipe de Asturias ${ }^{40}$.

- Del personal al servicio de la Casa del Rey, que podría agruparse en: personal directivo, personal funcionario y personal laboral.

- De los medios materiales al servicio de la Casa del Rey.

- De la financiación de la Casa del Rey y de la administración de la dotación regia.

- De las relaciones externas de la Casa del Rey.

\section{VIII}

De cuanto hasta aquí se ha dicho, pueden extraerse, como más significativas, las siguientes conclusiones:

1.a) La naturaleza jurídico-administrativa de las funciones de organización, administración y gestión interna de la Casa del Rey, como Administración de carácter Medial.

2.a) La fuerza expansiva del Estado de Derecho y la razón de ser del derecho a la tutela judicial efectiva, como presupuesto jurídico para la existencia de un control jurisdiccional de la actuación administrativa de la Casa del Rey.

3.a) El sometimiento a la normativa presupuestaria y contable de los actos de gestión patrimonial y de gestión financiera de la Casa del Rey, como presupuesto económico para la existencia de un control contable de la actuación presupuestaria de la Casa del Rey.

4.a) La articulación jurídica de los controles jurisdiccionales contencioso-administrativo y contencioso-contable de la Administración de la Casa del Rey en el marco constitucional.

5.a) A modo de consideración final de lege ferenda, la necesaria promulgación de un Estatuto de la Casa del Rey, que, como funda-

40 Cfr. sobre este último particular, ToRRes del Moral, A.: El Príncipe de Asturias. Su Estatuto jurídico, op. cit. 
mentamos en este trabajo, debe convertirse en realidad en nuestro Derecho Constitucional.

Para concluir el presente estudio, es necesario poner especial énfasis en la importancia que, a nuestro juicio, tiene una adecuada regulación de la Administración de la Casa del Rey y su control jurisdiccional en nuestro Derecho Constitucional, concretándose, mediante la correspondiente articulación normativa, en el Estatuto de la Casa del Rey, que propugnamos. Desde nuestro punto de vista, ambas cuestiones - la existencia de control jurisdiccional y la promulgación del Estatuto- no suponen sino un claro reforzamiento del papel de la Corona en el contexto de la Monarquía parlamentaria y en el marco del Estado de Derecho.

Y ello es así porque la Corona, por su especial significación como poder que desempeña la Jefatura del Estado, no puede carecer de un Estatuto que decididamente regule un órgano tan trascendental y de tan variadas funciones, como la Casa del Rey, y porque, además, el carácter ejemplarizador propio de la Corona, como poder de arbitraje y de moderación y como Magistratura simbólica, ha de reforzar un principio constitucional inherente a cualquier actuación jurídica de todo Estado de Derecho: la plenitud de control jurisdiccional. 